\title{
Construction of new houses \\ on a uranium vein outcrop: a case study from the Czech Republic
}

\author{
Viktor Goliáš, \\ Gereltsetseg Tumurkhuu, \\ Pavel Kohn, \\ Ondřej Šálek, \\ Jakub Plášil, \\ Radek Skoda, \\ Jan Soumar
}

\begin{abstract}
Significant uranium mineralization represented by a typical assemblage of uranyl supergene minerals in a quartz-uraninite vein hosted in the exocontact zone of the Variscan-Tanvald granite was found at a new construction site in the municipality of Jablonec n. Nisou. Activities of ${ }^{222} \mathrm{Rn}$ in soil gas reached $1 \mathrm{MBq} / \mathrm{m}^{3}$ around two houses, with a maximum of $3.33 \mathrm{MBq} / \mathrm{m}^{3}$ between them on a uranium ore lens outcrop. The uranium content reaches up to $291 \mathrm{ppm} \mathrm{eU}\left(3595 \mathrm{~Bq} / \mathrm{kg}{ }^{226} \mathrm{Ra}\right)$, and it is possible to find many 'hot' pieces of uranium ore fragments with a high percentage of uranium in the Quaternary cover in this place. This unfavourable situation is a result of an improper spatial planning process. The constructor was given the permission to construct the building even though the construction site did not meet safety requirements and the geological survey had failed. Not only geological prospecting was underestimated, but also the radon risk assessment was undervalued.
\end{abstract}

Key words: Tanvald granite $\bullet$ vein-type uranium $\bullet$ uranyl minerals $\bullet$ spatial planning $\bullet$ radon risk

V. Goliáš ${ }^{\bowtie}$, G. Tumurkhuu, P. Kohn

Institute of Geochemistry, Mineralogy and Mineral Resources,

Faculty of Science,

Charles University in Prague,

Albertov 6, 128 43, Prague 2, Czech Republic,

Tel.: +42022195 1511, Fax: +42022195 1496,

E-mail: wiki@natur.cuni.cz

O. Šálek

Institute of Hydrogeology, Engineering Geology

and Applied Geophysics,

Faculty of Science,

Charles University in Prague,

Albertov 6, 128 43, Prague 2, Czech Republic

J. Plášil

Institute of Physics, ASCR, v.v.i.,

Na Slovance 2, 182 21, Prague 8, Czech Republic

R. Škoda

Institute of Earth Sciences,

Faculty of Science,

Masaryk University,

Kotlářská 2, 611 37, Brno, Czech Republic

J. Soumar

Department of Mineralogy and Petrology,

National Museum,

Cirkusová 1740, 193 00, Prague 9, Czech Republic

Received: 4 January 2016

Accepted: 31 March 2016

\section{Introduction}

Residential radon exposure is considered a risk factor for lung cancer $([1,2]$ and others) but there is a lot of controversy on this topic; some authors suggest that it is only an assumption [3, 4]. On the other hand, a short-term radon exposure can be healthy from the balneological point of view, as we know from many spas around the world $[5,6]$. In all cases, radon is an object of interest for many scientists, as was clearly seen at the Krakow scientific conference in 2015 (radon2015.pl), where we presented this report in a preliminary form.

Our research group does not participate in a radon risk programme and this scientific study originated as a byproduct of a campaign for radioactive medicinal springs and consequent investigation of the particular geological unit. We were surprised and disappointed by the situation, as will be described later in this study. We believe that this case-study can also be helpful to the representatives of radon programmes of individual countries, and therefore we decided to publish it and make it thus accessible to the broader audience.

\section{Occurrence of uranium mineralization at a construction site}

The studied site is located in the northern part of the Bohemian Massif in the Lusatian zone. It is built mainly of Proterozoic to Early Palaeozoic 
metamorphic rocks. The area is penetrated by the large Krkonoše-Jizera (K-J) granite pluton of the Carboniferous age (317-320 Ma) [7]. The south-western part of the K-J pluton is composed of Tanvald alkaline granite, which differs geochemically and also by the content of radioactive elements; it is a real 'uranium granite'. Unlike other types of granite (Jizera, Liberec and Harrachov granites of the K-J pluton) that have $\mathrm{U} / \mathrm{Th}$ ratio ranging from 0.36 to 0.57 , Tanvald granite has a U/Th ratio of 1.04 [8].

Our research group carried out an exploration campaign for radioactive medicinal springs in the Tanvald granite area during the years 2014-2015. Twenty springs with activities above $1500 \mathrm{~Bq} / \mathrm{L}$ of ${ }^{222} \mathrm{Rn}$ (i.e. radioactive mineral water according to the Czech Spa Act) have been found [9].

The most important source was found during September 2014 in the southern part of Jablonec $\mathrm{n}$. Nisou in one of the largest city parks. Radon in water activity of this water source is $2255 \mathrm{~Bq} / \mathrm{L}$ ${ }^{222} \mathrm{Rn}$, outflow $0.42 \mathrm{~L} / \mathrm{s}$. It was named 'Schindler spring' after Josef Schindler, a local 'water doctor'; follower of famous Vincenz Priessnitz. It is very interesting that the spring used to be a water source for a part of Kokonín (part of the Jablonec n. Nisou city) until the 1980s (North Bohemian Waterworks and Sewerage Company - personal communication). This spring flows from the pronounced Kokonín fault, which dislocates the granite contact about $1 \mathrm{~km}$ away (Fig. 1).

After the discovery of the Schindler spring, a detailed exploration of the surrounding area was carried out. It was found that a new housing construction area lies directly on the fault line. An outcrop with considerably elevated radioactivity was found close to the newly developed houses.

Several fragments of uranium ore were quickly identified in the Quaternary cover and the place

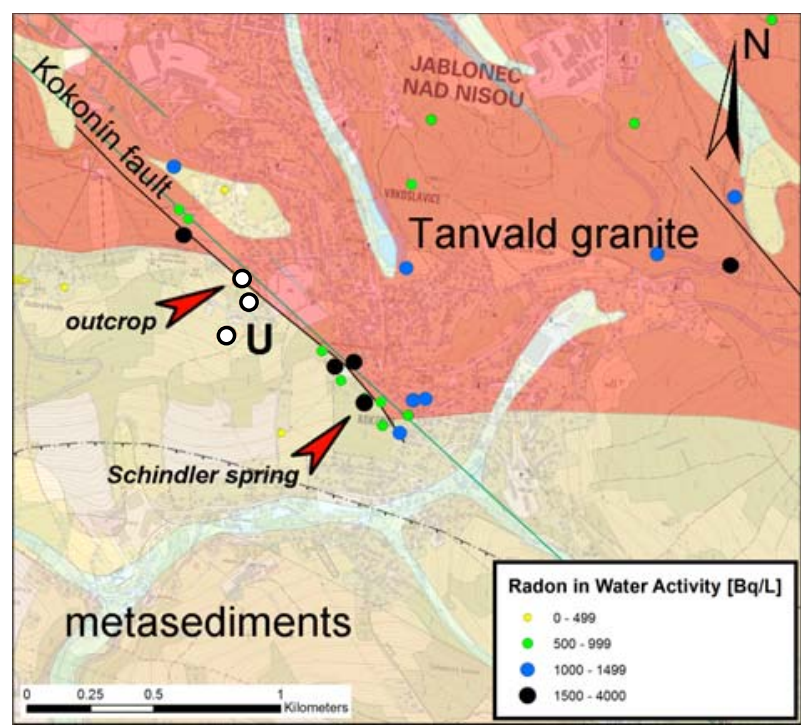

Fig. 1. Geological scheme of the Jablonec n. Nisou - Kokonín area with depiction of activity of water sources (adapted from [9]) and position of uranium lenses outcrops (white points) in the Tanvald granite exocontact zone. Base geological map 1:50 000 from the Czech Geological Survey WMS server http://mapy.geology.cz/arcgis/ services/Geologie/geocr50/MapServer/WmsServer. with the highest radioactivity was located just above one of the houses. Not too deep below the surface, a vein outcrop with a uranium ore lens was found by manual digging. Gamma dose rate reached $10 \mu \mathrm{Gy} / \mathrm{h}$ here. The surprised house owners, who had just moved in, were immediately informed.

The mayor and the head of the local building authority were also informed immediately. Information about discovery of the spring was accepted with pleasure, but not so the information about the uranium mineralization. The site was visited with the local authorities later.

\section{Materials and methods}

After an agreement with both the involved house owners, detailed geophysical measurements were carried out in March 2015, revealing how serious the situation was. Small areas around the houses were surveyed geodetically and measured by field gamma spectrometry and soil emanometry. The survey was performed in a geodetically established grid with a field gamma spectrometer GT-32T (GEORADIS, CR) with $2 \times 2$ inch bismuth germanium oxide crystal detector. Time of measurement was $2 \mathrm{~min}$. The detector was placed directly on the ground and then in a height of $1 \mathrm{~m}$ above the ground ( $2 \pi$ geometry). The RP-25 emanometer (ZMA, CR) with a $0.43 \mathrm{~L}$ ionization chamber was used for establishing the activity of radon in the soil. Both equipments were properly calibrated using modern approaches [10].

In the same term of spring geophysical action (March 25 and 26, 2015), measurements of indoor radon in House \#1 was also realized; RADIM II equipment (PLCH-SMM, CR) was used for the measurement.

Measurements of the wider territory were performed from June 15-20, 2015 and March 17, 2016. The same device was used for measuring the detail area between the houses - field gamma spectrometer GT-32T. The area was measured on irregular profiles perpendicular to the fault line about $20 \mathrm{~m}$ apart in the dynamic measuring regime. Counting time was $5 \mathrm{~s}$ for total gamma dose rate and 2 min for spectrometry, with data recording for $30 \mathrm{~s}$ (so this data were slightly smoothed by its methods). GPS logger, communicating with the device via bluetooth, recorded positions of measured points. The isoline maps were calculated by the Surfer software from the obtained data and after it was superimposed in GIS environment (ArcMap 10.2) on cadastral maps of the territory.

Some of the ore fragments collected on-site were investigated by X-ray PANalytical diffractometer X'Pert PRO with $\mathrm{Cu} \mathrm{K \alpha}$ radiation and X'Celerator detector (PXRD) and also by electron probe microanalysis with wave dispersion spectrometry (EPMA-WDS).

\section{Results}

The ore vein outcrop is located approx. $10 \mathrm{~m}$ above House \#1, on a ramp leading to House \#2. 


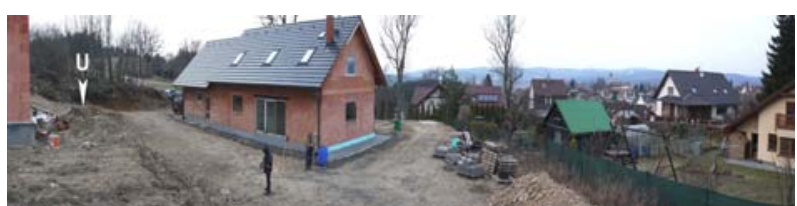

Fig. 2. Panoramic photo of the building site studied, 26 March 2015. House \# 1 is in the middle; corner of the House \#2 is on the left side. On the right is a view of the Jablonec city. Uranium vein outcrop (indicated by white arrow) is placed on the ramp between both the houses. Photo by Jakub Plášil, with permission of House \#1 owner.

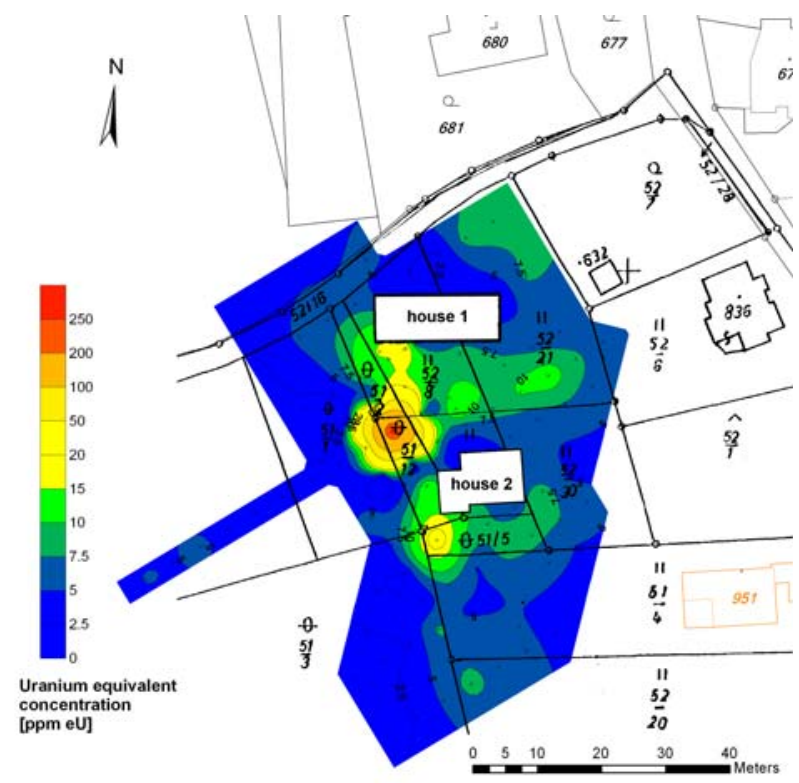

Fig. 3. The uranium map based on detailed gamma spectrometry measurement, superimposed on cadastral map of the building site. Measuring grid was $10 \times 5 \mathrm{~m}$ and $5 \times 5 \mathrm{~m}$ on anomaly area; total of 98 points.

A Quaternary solifluction flow with increased radioactivity, containing ore fragments, creeps down under the corner of the House \#1 (Fig. 2). On the basis of the field gamma spectrometric measurement, the activity of the flow was found to be about $260 \mathrm{~Bq} / \mathrm{kg}$ of ${ }^{226} \mathrm{Ra}$. The activity reached $3595 \mathrm{~Bq} / \mathrm{kg}$ of ${ }^{226} \mathrm{Ra}$ above the uranium vein outcrop (Fig. 3). The radioactive material was partially dispersed over the area of the construction site around both houses at the time of the final terrain works before the houses were constructed. The most affected are areas were located in the space between the houses. The result of the emanation survey reveals the extreme levels radon concentrations in the soil, which reached $1 \mathrm{MBq} / \mathrm{m}^{3}$ close to both houses, with a maximum concentration of $3.3 \mathrm{MBq} / \mathrm{m}^{3}$ of ${ }^{222} \mathrm{Rn}$ near the vein outcrop (Fig. 4).

The counts of $1684 \mathrm{~Bq} / \mathrm{m}^{3222} \mathrm{Rn}(t=45.3$ hours) of indoor radon in House \#1 was reached, even when the house concrete baseplate was insulated with two layers of sandwich plastic foil with aluminium and the baseplate was underlain by ventilation pipes in coarse permeable gravel (as required by the law). The long-term indoor radon measurements will proceed, but measured short-term radon activities also indicate a serious problem.

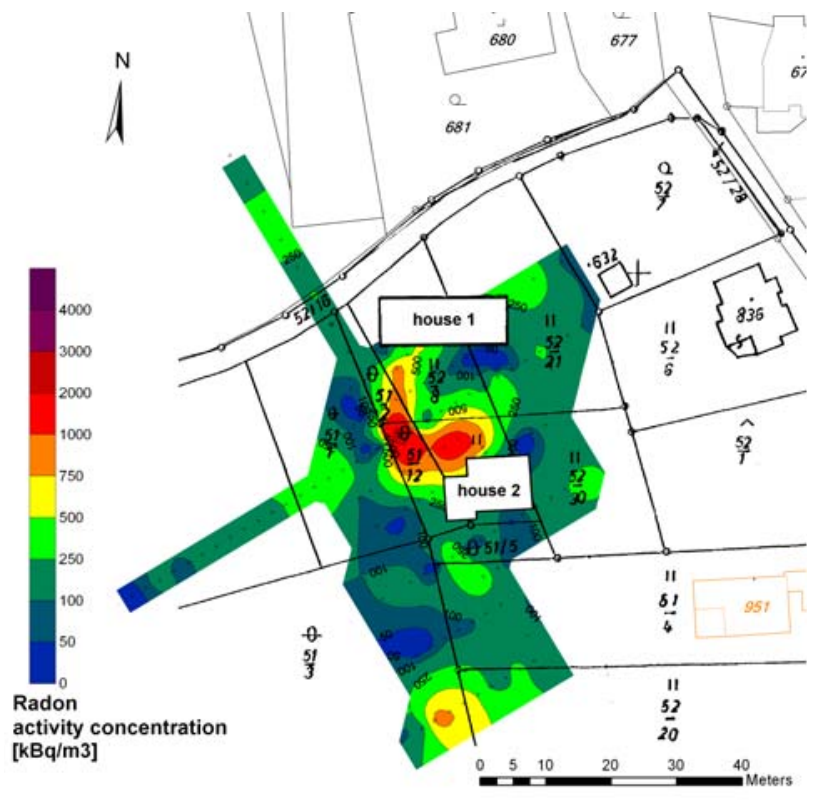

Fig. 4. Map of the radon activity concentrations in soil gas based on emanometric measurements, superimposed on cadastral map of the building site. Measuring grid was $10 \times 2.5 \mathrm{~m}$ and $5 \times 2.5 \mathrm{~m}$ on anomaly area; total of 109 points. The north side of House \#1 could not be measured because the area was covered with thick concrete pavement.

\section{Description of the uranium ore outcrop and its mineralogy}

The described location is situated almost exactly on the Kokonín fault line (Fig. 1), although the situation is not clear, because only a few bedrock outcrops are located in the broader vicinity of the studied site. The ore lens outcrop lies in the close exocontact zone of the Tanvald granite. The country rock is dark mica schists, affected by contact metamorphism (silicified and locally biotite recrystallized to the nest-like aggregates). The described ore zone does not have the same direction as the main fault; it is splayed more to the south of it. Three uranium ore lens outcrops were found in a broader area. The first was discovered at the building site described above, the second one was clearly indicated by the emanometry in the southern profile (Fig. 4) and the third one was found further to the south by the gamma spectrometry field prospection works of a wider area, covering the ore-zone extension, far away from the granite contact.

Small excavation works were carried out on the first ore outcrop. It was geologically documented and sampled (Fig. 5). A subvertical quartz vein in the north-south direction was found at the site. At least three generations of quartz appear there. First is massive, light gray quartz of great thickness; it is followed by the white quartz with uranium mineralization, of which the thickness reaches up to about $10 \mathrm{~cm}$. The last generation is comb-like quartz with crystals in cavities within the central suture of the vein. Not only a subvertical main vein was documented by the excavation works, but also a thinner, very flat splay 
NE

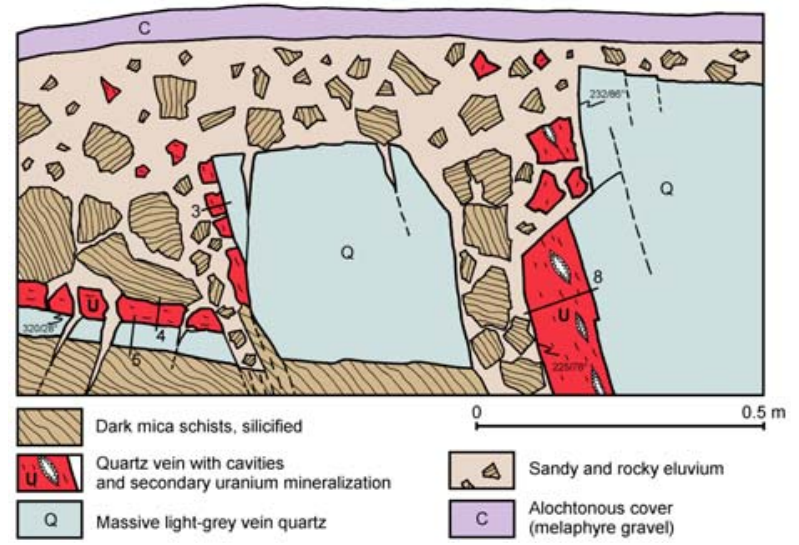

Fig. 5. Geological documentation of the uranium vein outcrop on the building site on a detailed scale. Documented by Viktor Goliáš, 26 March 2015.

vein carrying the uranium mineralization (Fig. 5), as well. The ore outcrop is highly affected by weathering in the supergene zone; many fragments are loose in the sandy-rocky eluvium.

A typical association of uranyl, $\left(\mathrm{UO}_{2}\right)^{2+}$, minerals was found in the collected ore fragments. Hydrated relics of uraninite (var. pitchblende, Fig. 6), massive

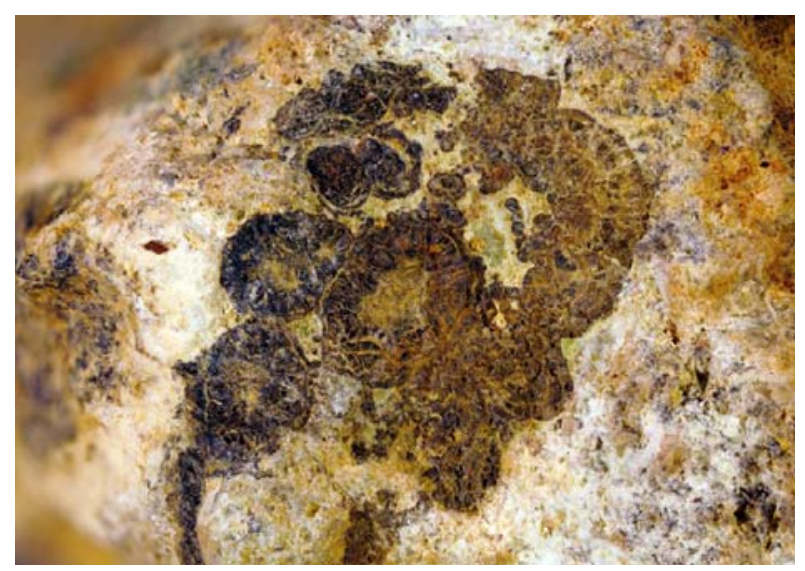

Fig. 6. Borytroidal uraninite (var. pitchblende) affected by hydration-oxidation weathering in the white quartz. Dark brown to olive green masse is an XRD-amorphous phase with slight admixture of zeunerite. FOV $11 \mathrm{~mm}$. Photo by Pavel Škácha.

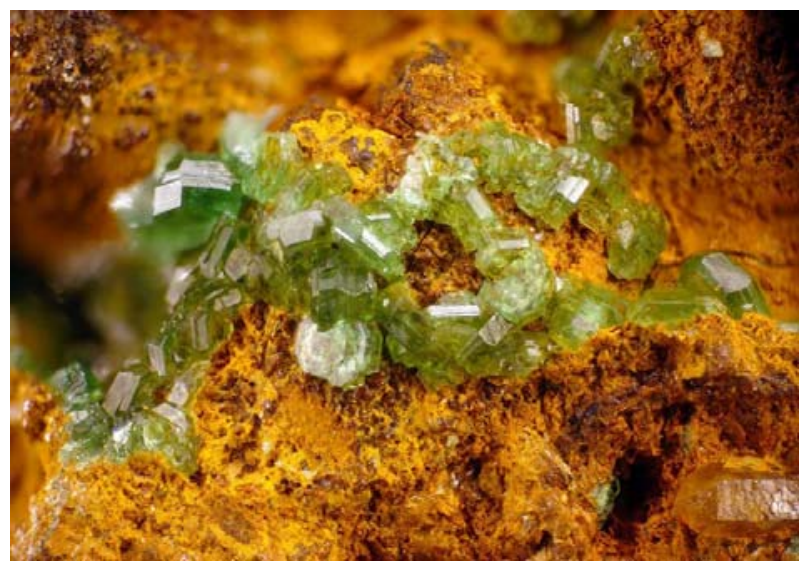

Fig. 7. Well-developed shiny tabular crystals of zeunerite, $\mathrm{Cu}\left(\mathrm{UO}_{2}\right)_{2}\left(\mathrm{AsO}_{4}\right)_{2} \cdot 12 \mathrm{H}_{2} \mathrm{O}$, tetragonal, on iron(III) hydrated oxides, FOV $4 \mathrm{~mm}$. Photo by Pavel Škácha. aggregates of 'gummite' - such as pseudomorphs after the primary uraninite in quartz, zeunerite (Fig. 7), bassetite and walpurgite are very common. Another rich ore fragment contains grains of native $\mathrm{Bi}$ with inclusions of $\mathrm{Ag}-\mathrm{Pb}-\mathrm{Bi}$ sulphosalts from the lillianite-gustavite series of minerals preserved in masses of cubic Bi-oxide (sillénite), occurring in an association with other bismuth and uranyl secondary phases. As seen from macrotextural relations, primary bismuth mineralization seems to be slightly older than the uranium. A detailed mineralogical research will proceed.

\section{Comparison with other localities of uranium mineralization in the same unit}

For us - geologists - such occurrence of uranium mineralization at this location and geological position is not so surprising. Similar sites occur along the exocontact zone of the K-J pluton, strung like beads on a string. Moreover, the Kokonín fault is the most significant tectonic structure throughout the whole body of the Tanvald granite. This new U-occurrence is similar to other uranium occurrences in Bohemian Massif/Erzgebirge; e.g. Jáchymov-type with U-Co-Ni-Bi-Ag association [11], and is also very similar to occurrences located close to the studied site in the exocontact zone of the Krkonoše-Jizera granite pluton (Fig. 8). In particular, it is the well-known U-occurrence of Rádlo, located nearby (about $2.5 \mathrm{~km}$ far to the west). The similarly tied association of $\mathrm{U}$ and $\mathrm{Bi}$ resembles the mineral association found at the Medvědín uranium deposit $[15,16]$. In the meantime, it can be classified just as an uranium occurrence; unfortunately, the exploration work will not proceed in the future as it is in the residential area.

\section{New measurement of the wider area}

After an agreement with the municipality of the Jablonec n. Nisou city, surface measurement of gamma spectrometry oriented along the Kokonín fault line in an area of about $0.25 \times 1 \mathrm{~km}$ was done (Fig. 9).

Anomalies of the equivalent uranium activity (uranium mineralization outcrops) were recorded in the known outcrop place between the new buildings (uranium ore lenses \#1 and \#2). Another anomaly of equivalent uranium concentration was detected on the radioactive Schindler spring outflow. Recently, a third lens of uranium mineralization was found. It is located further away from the contact with granite, to the south of the lenses \#1 and \#2. Like the lens \#2, it is covered by Quaternary cover, but the signal is significant, with considerable dispersion of radioactivity along the slope. Fortunately, this uranium mineralization outcrop is placed in a meadow, which is not a construction site according to the current land-use plan. However, the municipal authorities must be aware of this in the future when formulating a new land-use plan. 


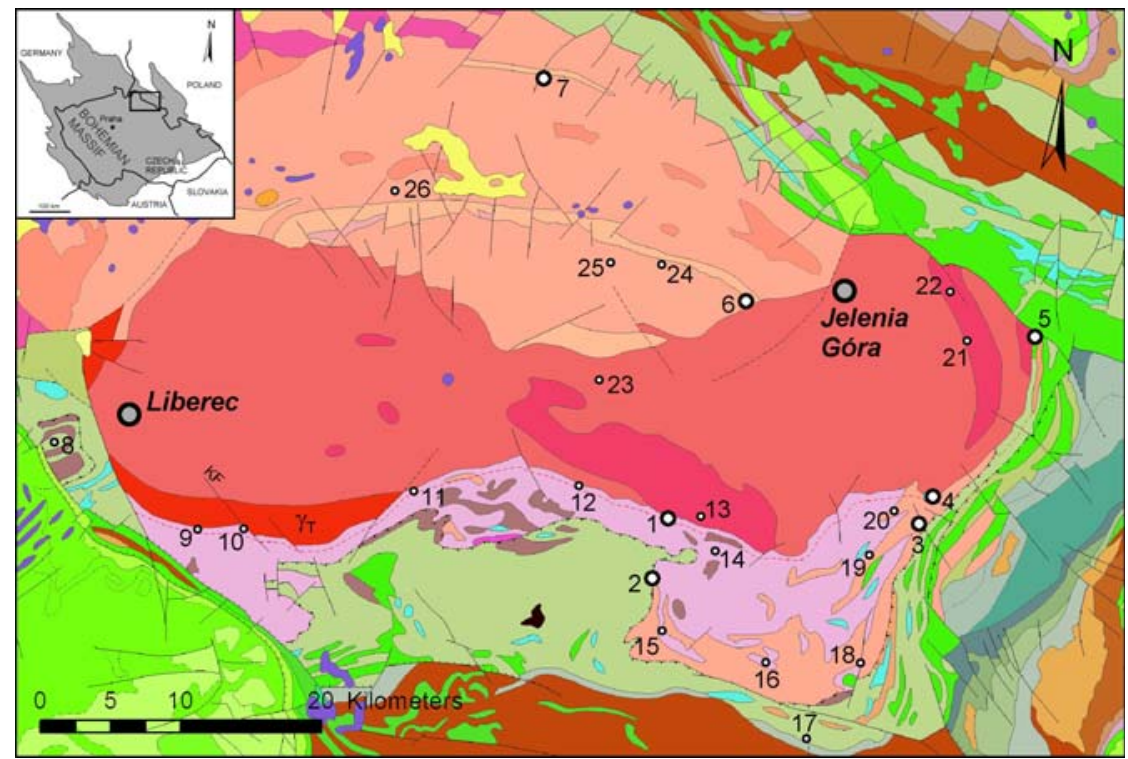

Fig. 8. Localities of uranium mineralization and its elemental association around the Krkonoše-Jizera granite pluton based on [12-14] and other sources. Base geological map 1:500 000 from the Czech Geological Survey WMS server http://mapy.geology.cz/arcgis/services/Inspire/GM500K/MapServer/WMSServer. KF = Kokonín fault, $\gamma_{\mathrm{T}}=$ Tanvald granite body. Uranium deposits (>10 t U): 1 - Medvědín U-Bi(Ag); 2 - Labská U(Pb); 3 - Kowary-Podgórze U(Cu, Pb); 4 - Kowary-Wolność U-Bi-Co-Ni-Ag; 5 - Medzianka U-Cu(Bi); 6 - Wojcieszyce U(Pb); 7 - Radoniów U(Pb). Uranium occurrences (<10 t U): 8 - Křižany U(Co, Ni); 9 - Rádlo U(Ag); 10 - Kokonín U-Bi(Ag); 11 - Př́íchovice U-Cu(Pb); 12 - Rýžoviště U-Bi; 13 - Bílé Labe U-Cu-Mo; 14 - Svatý Petr U-Cu-Pb-Zn(Ag, Bi); 15 - Herlíkovice U(Co, Ni); 16 - Černý Důl U-Cu(Ag); 17 - Bolkov U; 18 - Maršov U; 19 - Horní Malá Úpa U-Ti; 20 - Wolowa Góra U-Th-Ti; 21 - Trzcińsko U-Mo; 22 - Maciejowa U-Mo; 23 - Szklarska Poręba U-Bi-Mo; 24 - Kromnów U; 25 - Kopaniec U(Cu); 26 - Pobiedna U.

\section{Discussion and conclusions}

The area was investigated in the 1950s during extensive exploration for uranium, namely the emanation survey on a very detailed scale of 1:5000, however, with negative results. Quality of the survey was later evaluated to be insufficient [17]. Nevertheless, this is not the main reason.

The mandatory radon-risk report of the House \#1 is of the relatively high level, reviewed by one insider of the Czech Rn-programme. (The Rn assessment report of the House \#2 was impossible to obtain from the owner). The company (kept anonymous) responsible for the measurements provided the data listed in Table 1. Compared with our data from the whole area, it is obvious that they are undervalued. High values were reached (though not as extreme as we obtained there). Its nuclear, why the measured activities were taken into consideration by the company who evaluated the risk, as being too high on the area built by schists? About 100 m away from the site, yet on granite, such numbers would not be so surprising! As a good joke, we have to consider the conclusion of the Rn-risk assessment: "Measured values of their nature and distribution correspond to area without faults and significant local anomalies". However, the mentioned company did not have relevant qualification (they simply were not geologists) and, in our opinion, not detecting the problem was not their fault, primarily. The Rn-risk survey was done correctly here, in accordance with the modern methodology [18], as well as according to the current Czech laws.

Mandatory radon risk survey is then just a mere caricature of the geological work. In addition, most



Fig. 9. Uranium map of the wider area around the Kokonín fault based on gamma spectrometric data; calculated from 1637 measured points in total and superimposed on cadastral map of the whole area. Clearly visible is the Schindler radioactive spring outflow and also position of outcrops of three uranium lenses in the granite exocontact zone. 
Table 1. Comparison of the data from Rn-risk assessment for House \#1 (with permission of owner) with our data measured by soil emanometry. Although, it was probably not measured in exactly the same area, it is clear that the results of mandatory Rn-risk assessment are underestimated

\begin{tabular}{lcc}
\hline \multicolumn{1}{c}{ Value } & $\begin{array}{c}\text { Current Rn risk assessment } \\
\text { for House \#1 }\end{array}$ & $\begin{array}{c}\text { Our data } \\
\text { (after }{ }^{220} \text { Rn correction) }\end{array}$ \\
\hline Number of points & 15 & 109 \\
${ }^{222} \mathrm{Rn}\left[\mathrm{kBq} / \mathrm{m}^{3}\right] \min$ & 17.6 & 7.2 \\
${ }^{222} \mathrm{Rn}\left[\mathrm{kBq} / \mathrm{m}^{3}\right] \max$ & 274 & 3330 \\
${ }^{222} \mathrm{Rn} 3 \mathrm{rd}$ quartile $\left[\mathrm{kBq} / \mathrm{m}^{3}\right]$ & 200 & 360 \\
$\mathrm{Rn}$ index & High & High \\
\hline
\end{tabular}

of the companies are simply not represented by geologists. Measurements are performed on a commercial basis; the current price of assessment is about 60 EUR only. Therefore, companies carry out the survey under great economic pressure and often issue falsified reports (probably not in this case).

Two young families with children, who built their houses on the studied site, should be considered victims of the system. The owner of the House \#2 has not cooperated with us and is continuously ignoring the alarming values and warnings. The owner has refused even to perform a long-term indoor $\mathrm{Rn}$ measurement. It was difficult to negotiate an agreement for detailed measurements on the site of the house.

The owner of the House \#1 was interested in the research and wants to resolve the unfavourable situation. That is why we have also contacted the owner with the responsible person from the Czech Technical University to help him deploy active ventilation under the home baseplate in a better way. We also recommended to him to cover up the uranium ore lens outcrop on the road with a solid surface and Quaternary soilfluxion flow near the house (in the garden) overlie with a soil cover. Furthermore, we think that it is an unfortunate place to live from the geomedicinal point of view. It goes about a place located above a fault line, where geophysical and biophysical fields are broken, cf. [19]. Moreover, we also expect elevated concentrations of arsenic in the outcrop, as the majority of the supergene minerals found there are arsenates.

Problems described above have become a political case at the municipality of the Jablonec city in the meantime. We found out that the municipality knew about the problem of increased radioactivity at the site, but did not pay attention to them because of the changes of personnel in the office. Generally, the main problem is that geologists are not involved in spatial planning on a larger scale. That is why localities with a high potential geological risk might become construction sites. This practice is widely criticized by the geological community, not only in the Czech Republic.

Current Rn-risk programme seems to be toothless as it exists. It does not serve to assess the real risks and does not help to find solutions for such localities as we have described here. And after the assessment, it is also too late for any changes after the particular site is classified as a building site.

This report, presented at the Krakow conference and at the 13th SGA biennial meeting in Nancy, attracted a large response in a broader scientific community. According to information provided by other scientists, similar cases have happened in other countries, too (France, Ireland, Spain...). Therefore, we believe that it would be good to invite geologists into national radon programmes and for spatial planning as well (because radon risk is a geogenic risk at the first place). Such cases could then be detected early enough and we could increase the chance of preventing them.

Acknowledgments. We are indebted to Prof. Milan Matolín for fruitful discussions on the topic; Ing. Ivana Řimnáčová, head of the Building Department of the Jablonec city, for her cooperation; and students and other radioactive springs fans for their selfless help in the field. We also thank the projects OPPK CZ.2.16/3.1.00/21516 and GAUK 756213 for financial funding.

\section{References}

1. Zhang, Z. L., Sun, J., Dong, J. Y., Tian, H. L., Xue, L., Qin, L. Q., \& Tong, J. (2012). Residental radon and lung cancer risk: An updated metaanalysis do case-control studies. Asian-Pac. J. Cancer Prev., 13, 2459-2465. DOI: 10.7314/APJCP.2012.13.6.2459.

2. Al-zoughool, M., \& Krewski, D. (2009). Health effects of radon: a review of the literature. Int. J. Radiat. Biol., 85, 57-69. DOI: 10.1080/09553000802635054.

3. Fornalski, K. W., \& Dobrzyński, L. (2011). Pooled Bayesian analysis of twenty-eight studies on radon induced lung cancer. Health Phys., 101(3), 265-273. DOI: 10.1097/HP.0b013e31821115bf.

4. Fornalski, K. W., Adams, R., Allison, W., Corrice, L. E., Cuttler, J. M., Davey, C., Dobrzyński, L., Esposito, V. J., Feinendegen, L. E., Gomez, L. S., Lewis, P., Mahn, J., Miller, M. L., Pennington, C. W., Sack, B., Sutou, S., \& Welsh, J. S. (2015). The assumption of radon-induced cancer risk. Cancer Causes Control, 26(10), 1517-1518. DOI: 10.1007/s10552-015-0638-9.

5. Deetjen, P., Falkenbach, A., Harder, D., Jöckel, H., Kaul, A., \& Philipsborn, H. V. (2005). Radon als Heilmittel. Terapeutische Wirksamkeit, biologischer Wirkungsmechanismus und vergleichende Risikobewertung. Hamburg: Verlag Dr. Kovac.

6. Franke, A., Reiner, L., \& Resch, K. L. (2007). Long-term benefit of radon spa therapy in the rehabilitation of rheumatoid arthritis: a randomised, double-blinded trial. Rheumatol. Int., 27(8), 703-713. DOI: 10.1007/ s00296-006-0293-2.

7. Žák, J., Verner, K., Sláma, J., Kachlík, V., \& Chlupáčová, M. (2013). Multistage magma emplacement and progressive strain accumulation in the shallow-level Krkonoše-Jizera plutonic complex, 
Bohemian Massif. Tectonics, 32, 1493-1512. DOI: 10.1002/tect.20088.

8. Černík, T., \& Goliáš, V. (2014). Radioactivity of granitoids of the Krkonoše-Jizera pluton: Statistical analysis of archival data. Geosci. Res. Rep., 2013, 103-106. http://www.geology.cz/zpravy/en/detail/ Zpr2013D-2 (in Czech).

9. Kohn, P. (2015). Springs of the radioactive mineral waters on Tanvald granite. Unpublished M.Sc. thesis, Charles University in Prague, Faculty of Science, Prague, Czech Republic.

10. International Atomic Energy Agency. (2003). Guidelines for radioelement mapping using gamma ray spectrometry data. Vienna: IAEA. (IAEA-TECDOC-1393).

11. Ondruš, P., Veselovský, F., Gabašová, A., Hloušek, J., \& Šrein, V. (2003). Geology and hydrothermal vein system of the Jáchymov (Joachimsthal) ore district. J. Czech Geol. Survey, 48(3/4), 3-18. http://www. jgeosci.org/content/JCGS2003_3-4_ondrus1.pdf.

12. Mochnacka, K., Oberc-Dziedzic, T., Mayer, W., \& Pieczka, A. (2015). Ore mineralization related to geological evolution of the Karkonosze-Jizera Massif (the Sudetes, Poland) - towards a model. Ore Geol. Rev., 64, 215-238. DOI: 10.1016/j.oregeorev.2014.07.001.

13. Nieć, M. (2009). Occurrences of uranium ore in Poland and possibilities for prospecting for uranium deposits. Polityka Energetyczna, 12(2/2), 435-451. https://www.min-pan.krakow.pl/se/pelne_teksty23/ k23z_pe/k23_niec_z.pdf (in Polish).
14. Veselý, T. (1982). Small uranium deposit of crystalline of the Bohemian Massif. Part III: North and northwest Bohemian area. Geol. Hydrometal. Uranium, 6(3), 3-46 (in Czech).

15. Plášil, J., Sejkora, J., \& Goliáš, V. (2008). Bismuth mineralization from the Medvědín uranium deposit near Špindlerův Mlýn. Opera Corcontica, 45, 5-11. http://opera.krnap.cz/_pdf/45/OC-45-1.pdf (in Czech).

16. Plášil, J., Sejkora, J., Čejka, J., Škoda, R., \& Goliáš, V. (2009). Supergene mineralization of the Medvědín uranium deposit. J. Geosci., 54, 15-56. DOI: 10.3190/ jgeosci.029.

17. Kadlčíková, E. (1975). The geological structure and perspectives for uranium exploration in the West-Sudeten area. Unpublished report, DIAMO State Enterprise Archive, Liberec (in Czech).

18. Neznal, M., Neznal, M., Matolín, M., Barnet, I., \& Mikšová, J. (2004). The new method for assesing the radon risk of building sites (Spec. Pap. 16). Praha: Czech Geological Survey. .

19. Selinus, O., Alloway, B., Centeno, J. A., Finkelman, R. B., Fuge, R., Lindh, U., \& Smedley, P. (Eds.). (2013). Essentials of medical geology: Revised edition. The Netherlands: Springer. DOI: 10.1007/978-94-0074375-5. 